\title{
COVID-19 in Indonesia: An Analysis of DKI Jakarta's COVID-19 Pandemic Response and Its Governance During the New Normal Period
}

\author{
Saut Sagala* \\ School of Architecture, Planning and \\ Policy Development \\ Bandung Institute of Technology \\ Bandung, Indonesia \\ saut.sagala@gmail.com \\ Danang Azhari \\ Disaster and Climate Resilience \\ Resilience Development Initiative \\ Bandung, Indonesia \\ dana.azhari@rdi.or.id
}

\author{
Arief Rosyidie \\ School of Architecture, Planning and \\ Policy Development \\ Bandung Institute of Technology \\ Bandung, Indonesia \\ ariefrosyidie@yahoo.com \\ Salma N. Annisa \\ Children, Social Welfare and Health \\ Resilience Development Initiative \\ Bandung, Indonesia \\ salma.annisa@rdi.or.id \\ Muhammad Dimas Mahardika \\ Faculty of Engineering \\ Gadjah Mada University \\ Yogyakarta, Indonesia \\ dimas.mahardika99@gmail.com
}

\author{
Amesta K. Ramadhani \\ Disaster and Climate Resilience \\ Resilience Development Initiative \\ Bandung, Indonesia \\ amesta.kartika@rdi.or.id
}

Rufaida N. Vicri

Children, Social Welfare and Health

Resilience Development Initiative

Bandung, Indonesia

rufaida.nurul@rdi.or.id

\begin{abstract}
Since the first cases in Early March 2020 until August, Jakarta is still the epicenter of the spread of the COVID-19 in Indonesia. Entering the seventh month of the outbreak the situation in Jakarta has been spiraling beyond control, indicated by a sudden rise of COVID-19 confirmed cases. The cases' spikes may have been due to relaxed social restrictions policy and the more thorough test prior to August, as well as the lack of citizens' adherence to social distancing measures. Nonetheless government response and governance during the 'new normal' period are also pertaining to the resurgence of COVID-19 cases. Thus, this paper aims to give elaborated exposition on the COVID-19 governance of Jakarta Provincial government during the new normal era. And how is the difference in response to the first phase and second phase of COVID-19 social restriction (PSBB)? We observed government negligence in enforcing necessary policies and measures to slow down the spread during the new normal period is one of the major influences for the resurgence of COVID-19 cases, consequently the situation stimulates the Jakarta Government to take a more serious approach to the crisis. The findings of this paper will contribute to the development and advancement of policy response and crisis management of subnational government.
\end{abstract}

Keywords-DKI Jakarta, COVID-19, New Normal, Crisis Management, Policy Response

\section{INTRODUCTION}

Indonesia as the fourth most populous country in the world has predicted to suffer significantly due to COVID-19 pandemic [1]. Jakarta as the capital of Indonesia with the most populated urban area also predicted to be affected by the Corona Virus Disease (COVID-19) pandemic. In the early days, Jakarta had the highest positive case and death tolls. Currently, Jakarta also has the highest test rate in Indonesia (78.231 test rate per one million population), which was also higher than the national test rate $(6.430$ test rate per one million population). [2] However, since the first case in Early March 2020 until August, Jakarta is still the epicenter of the spread of the COVID-19 in Indonesia.

Jakarta has issued various policies in response to this current pandemic. One of them is the large-scale restriction (PSBB). PSBB based on Government Regulation (PP) Number 21 of 2020 concerning the accelerating management of COVID-19. PSBB policy as a middle-ground health quarantine policy that sought to save both public health and economic sector without implementing a total lockdown, it also known as partial lockdown. It aims to limit the community and some sectors' activities on a large scale. Jakarta was the first region to implement PSBB. The first phase of PSBB in Jakarta started in early April 2020. It supposedly lasted for two weeks. However, it ended up lasting for 3 months until early June 2020. The first phase of PSBB has proven to reduce the positive rate of COVID-19 in Jakarta [3].

The first phase of the PSBB was then replaced on 10th June by a transition phase to the 'new normal' which refers to co-existence with COVID-19 [4]. The transition is needed to support Jakarta which was suffering the economic downturn from the first phase of PSBB [5]. During the transition, strategic sectors and essential services can be started again gradually, but there are limitations and health protocol that must be obeyed. However, Entering the sixth month of the outbreak the situation in Jakarta has been spiraling beyond 
control, indicated by a sudden rise of COVID-19 confirmed cases.

Based on the data from Jakarta Health Agency since early June the COVID-19 positive case has gradually increased with the highest weekly positivity rate in Jakarta was noted at 9.6 percent per August 17th 2020 [6]. And 12th September was the peak of positive cases in Jakarta about 1,270 new cases. The cases' spikes may have been due to relaxed social restrictions policy and the more thorough test prior to August, as well as the lack of citizens' adherence to social distancing measures and health protocol proposed [7]. Moreover, Jakarta health agency also states that five types of COVID-19 clusters in Jakarta have occurred in this transitional phase, namely houses of worship, residential areas, markets, office and health facilities [8]. Nonetheless government response and governance during the transition to 'new normal' period are also pertaining to the resurgence of COVID-19 cases.

After facing various problems after the implementation of this transitional phase, the Jakarta Government has responded by reverting to implement the second phase of the PSBB, which starts on 14th September 2020. After all of the government response to this pandemic, it can be revealed the government's lack of crisis management on sudden and rapid spread of strain of Coronavirus (the SARS-CoV2) [9]. Crisis management is making decisions based on appropriate evidence and critical thought while working under unpredictable circumstances [10]. The Jakarta government's poor crisis management shows in the overtime response to this COVID-19 pandemic, and it must change. In order to develop good crisis management, formulating an appropriate response in crisis circumstances is crucial. In the face of COVID-19 resilience towards uncertainty of hazards is become more increasingly important. Adaptive governance is outlined to be capable of increase governance resilience [11]. Adaptive governance can be attained by increasing the adaptability and agility of current modes of governance to hazards, and in this case to the pandemic. A better understanding of the adaptability and agility of the current governance will give a better execution on crisis management.

Therefore, this paper aims to give an elaborated exposition on the crisis management of COVID-19 governance of Jakarta Provincial government during the transition phase to the 'new normal' era. In order to achieve these goals, there are several objectives that will be achieved, including:

1. Identify the current adaptability and agility of Jakarta Government in coping with the COVID-19 pandemic

2. Identify difference of crisis management between the first phase and second phase of COVID-19 social restriction (PSBB) in Jakarta

The following section will discuss the theoretical background and continue the result and discussion of the findings are presented. This paper mainly uses the qualitative approach. Data was obtained through secondary data surveys, including government documents, data, and policies, online newspapers, and journals. The analysis in this paper will mainly uses content analysis. Content analysis is a research technique for making replicable and valid inferences from texts (or other meaningful matter) to the contexts of their use [12]. The analysis mainly uses textual sources as a useful evidence for testing hypotheses and answering research questions [13]. The findings of this paper will contribute to the development and advancement of policy response and crisis management of the Jakarta government.

\section{LITERATURE REVIEW}

\section{A. Crisis Management}

A crisis ultimately may have the ability to produce three interdependent threats to: 1.) public safety; 2.) financial loss; and 3.) reputation loss. As crisis management is important, failure to implement it can result in severe harm to stakeholders and a considerable organizational losses [14]. Consequently, deriving from the premises that crisis can be recurrent and non-preventable, Pearson [15] posited that crisis management are efforts that can be labelled as effective when during a crisis "operations are sustained or resumed, organizational and external stakeholder losses are minimized, and learning occurs so that lessons are transferred to future accident" [15].

Crisis management is therefore a process designed to reduce the severity of the damage a crisis can lay upon an organization and its stakeholders. The phases of crisis management can be divided into three phases: 1.) pre-crisis; 2.) crisis response; 3.) post-crisis [14]. Barton [17] and Coombs [16] reported that organizations have the better ability to mitigate crisis when they: 1.) own a crisis management plan that is updated thoroughly and periodically; 2.) possess a designated crisis management team; 3.) hold simulations regularly to test the plans for the crisis; and 4.) draft a crisis message prior to its finalization [16], [17].

In relation to how crisis management can be contextualized in the incidences of health emergencies, the initial thing that must be assumed is that "a coordinated and effective operational action plan of certain groups of people exists, and it will be implemented in a case of imposed threat on civilians' health and health systems, regardless of the cause and its extent" [18]. Unmistakably, it implies that it is necessary to properly plan for a health crisis, both prior to the crisis and also after the crisis. Efstathiou et al. [18] also recommended that it is of utmost importance for health crisis managers to have relevant experiences in public health sectors [18]. The manager of a health crisis has to be periodically updated on global and domestic circumstances that may affect public health. Consequently, during a health crisis, the manager must assess the significance of the incidents and put the health of the population as the main priority.

Furthermore, to contextualize crisis management for the incidences of health emergencies, it is also necessary for the responsible authorities to properly define health emergency planning. Summarizing from the U.S. definition of public health preparedness planning and NHS definition of a major incident, Boyd et al. [19] defined health emergency planning as: "A coordinated, cyclical process of planning, implementation, evaluation and learning which aims to increase the capability of society to prevent, protect against, respond to, and recover from any occurrence which presents a serious threat to the health of the community, or disrupts the health care system, or causes (or is likely to cause) such numbers or types of casualties as to require special arrangements to be implemented by one or more health care organizations [19]." In Indonesia, the legal definition for health emergency crisis is written in Law on Health Care (No. 
6/2018) as: "Extraordinary public health incidences, denoted by the transmission of contagious diseases[20]."

\section{B. Agile and Adaptive governance}

The concept of adaptive governance (AG) found its roots from the research field of social-ecological systems and adaptive management (AM) back in the 1970s [21], [22]. Holling [21] contended that the process of learning and adaptation is crucial in the fields of management. The said process of learning and adaptation is continuous, and can be likened as an "active" scientific hypothesis testing "in the field" [21]. Subsequently, a more modern interpretation of this concept redescribed adaptive governance (AG) as a management which consisted of: 1.) a set of cycles that are adaptive; and 2.) a group of connections between changes that varies in their speed and scale [23]

The other scholarship branch of adaptive governance (AG) was developed from its initial concept and later was combined with the comprehension of adaptive management with a cooperative approach to managing local resources [11]. This AG scholarship group - which can be labelled as the cooperative management literature - focuses heavily upon the concept of shared resources (co-management). The concept of cooperative management can be observed in several societal activities, such as a manifestation of power-sharing arrangement between the State and a community of resource users [24]. Expanding upon those earlier concepts regarding cooperative management, Olsson [26] proposed that the concept of cooperative management has a group of common principles which always consists of a management process that is dynamic, multilevel, and polycentric [25], [26]

To increase the role of adaptive governance in its relation to resilience management in the context of natural hazards occurring, four important characteristics are needed [11]. Those characteristics can be broadly described as: 1.) polycentric and multilayered institutions; 2.) participation and collaboration; 3.) self-organization and networks; and 4.) learning and innovation. Resilience, when used in this context, can be defined as the main goal to decrease the risks of disasters occurrences [27].

Agile governance is rooted in the field of software development, and consequently, due to the multiinterpretative nature of its core concept, agile governance was later adopted by business and government [28]. Agile governance can be defined as "organizational culture and methods of collaboration to achieve a higher level of adaptiveness" [29]. The concept of agile governance, while fundamentally not so different from the concept of adaptive governance - in the terms of how response to change is both of their focus - there are several differences that need to be highlighted [30].

In the context of COVID-19 pandemic, the concepts of adaptive and agile governance may have the potential to be proven useful in analyzing governments' response to pandemic. Janssen and van Voort [30] argued that those concepts can be useful because "In the face of COVID-19, there was an urgency for the government to respond, and at the same time, there is a considerable uncertainty about the situation and the potential effectiveness of the measures proposed to stop the transmission [30].”. They also elaborated that the COVID-19 dictates that governments require adaptability especially in those following areas:
- Hospital capacity

- Testing and contact tracing

- Food supply assurance

- Medical equipment supply

- Prescription drug supply

- Funding to keep the economy running

Notwithstanding, there is still a need in how to interpret "government" in a more specific way, while discussing agile and adaptive governance in the light of COVID-19 pandemic. Janssen and van Voort [30], in their analysis, defined "government" as the entire system of public, private, and semi-public actors that collaborate in providing a service for the public good. [30]

\section{COVID-19 DEVELOPMENT IN DKI JAKARTA}

Jakarta has implemented the PSBB since 10th April 2020. The PSBB phase is divided into 3 phases, which are the first PSBB phase, the transition phase towards the 'new normal' era and the second PSBB phase. In the first phase of the PSBB, the Government of Jakarta made several extensions including on 23rd April, 22nd May and 4th June. Furthermore, the transition phase began to be implemented from 5 June 2020.

The transitional phase was held for 28 days or from 5 th June to 2nd July 2020. However, it was extended again by 14 days until 16th July 2020. Then, the transition phase underwent a second extension, starting from 17th-30th July 2020. Still continuing, Jakarta governance again extended The transitional phase for the third time on 30th July until 14th August 2020. For the fourth time, the Jakarta government extended the transitional phase for 14 days, from August 14th27th, 2020. And lastly, the Jakarta government extended the transition phase for the fifth time on August 27th -10th September 2020, before finally implementing the second phase of PSBB on 14th September 2020.

\section{A. Rapid Escalation of COVID-19 Trend}

Positive cases in Jakarta and Indonesia have been rapidly increasing since the first case on 2nd March 2020 (see Fig. 1). Jakarta is also the biggest contributor on the number of positive cases at the national level. When Jakarta enter its first phase of PSBB the number of positive cases per day has exponentially increase to 91 cases/ day, with a total of 1810 confirmed cases. Afterwards, the percentage of positive cases increase per day in Jakarta has gradually decreased, which are $18 \%, 18 \%$, and $-36 \%$. At this point, the first phase of PSBB reduces the positive rate of COVID-19 in Jakarta.

After the transition phase replaced the first phase of PSBB, the number of positive cases per day has been increasing significantly. In the first day of the transition phase, the number of positive cases per day in Jakarta are 147 cases, and has increased about $141 \%$ from the last day of the first phase of PSBB. Then, the percentage of positive cases increased per day in Jakarta continues to be high, and the highest percentage was $92 \%$ increasing. The transition phase to 'new normal' has increased the positive rate of COVID-19 in Jakarta.

After the second phase of PSBB was implemented, there has been a decrease of the percentage of positive cases 
increased per day about $-27 \%$. The accumulation of COVID19 positive cases in Jakarta also has been gradually increasing, on 20th September the accumulation of positive cases are 62,886 cases.

Fig. 2 shows that the death toll in Jakarta and Indonesia also has been gradually decreasing after the first phase of PSBB. And the biggest jump of the death toll in Jakarta was in the first day of the transition phase with the percentage of death toll increased per day about $300 \%$. And after the transition, the number of deaths also increased to 30 deaths on 14th September 2020. This increase in the number of deaths is likely due to the "alarming" shortages of beds needed to treat COVID-19 patients [10]. On 20th September the accumulation of death toll are 1,561 cases.

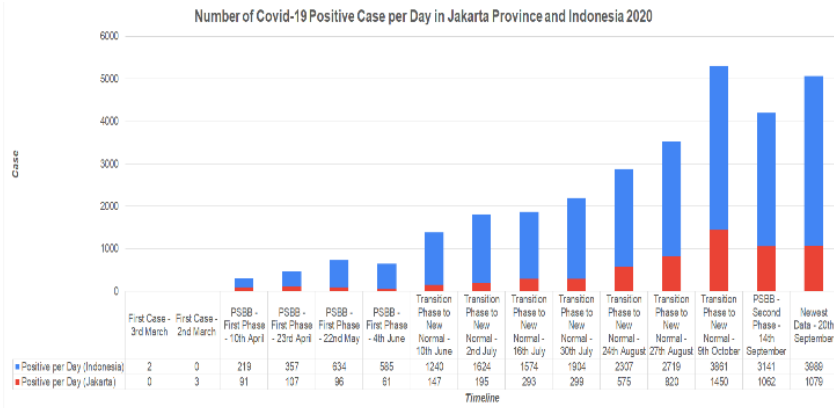

Fig. 1. Number of COVID-19 Positive Case per Day in Jakarta Province and Indonesia 2020

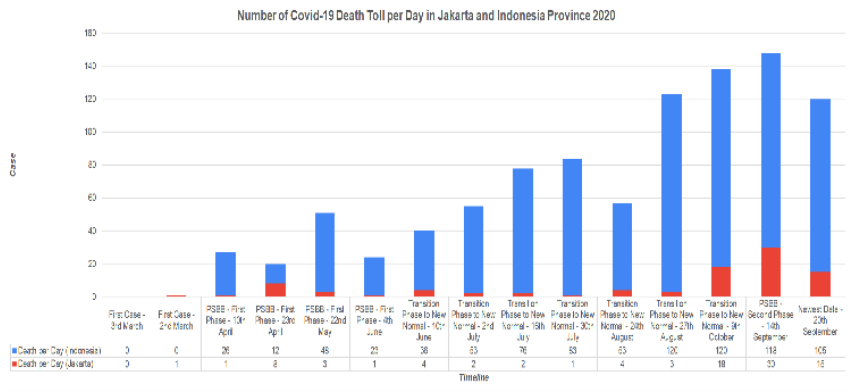

Fig. 2. Number of COVID-19 Death Toll per Day in Jakarta Province and Indonesia 2020

Fig. 1 \& 2. Both figures are based on Jakarta's COVID-19 monitoring website

\section{B. Change in Policies, Loose Monitoring System and Ramped up Testing Capabilities}

One of the catalysts for the COVID-19 outbreak acceleration in Jakarta reclines in the series of policies that was enacted by the government.

The most impactful one was the decision to replace the strict restrictions of the first phase of PSBB with the 'transition' phase, in which that phenomenon can be seen as a form of policy change. During the transition phase, there were several social restrictions that were lifted [31]

- Places of worship that were previously forbidden to be used for a mass prayer were then reopened, under the requirements that the health protocol must be enforced.

- Offices and factories were reopened, under the requirements that the manager of the business have to maintain that the number of employees working in the building is set at $50 \%$ of the building capacity.
- Restaurants were reopened, under the requirements that the maximum number of restaurant visitors is to be maintained at $50 \%$ of the capacity. Cashless payments are encouraged and only a la carte dining is permitted.

- Online motorcycle taxis were also given a permit to operate and restrictions on private vehicle passenger capacity were also lifted.

- Shopping centers for non-essential retailers were reopened, under the requirements that the visitor must be kept below $50 \%$ of the maximum capacity.

- Outdoor sports, social, and cultural activities were also given the permission to be continued. Outdoor sport centers, museums, libraries, galleries, and childfriendly integrated public spaces were reopened, under the requirement that visitors must be kept $50 \%$ below the building capacity.

For other sectors, the Jakarta government made the decision that educational facilities, wedding receptions, event venues, theaters, recording studios, film production facilities, nightlife entertainment, boutique, and karaoke were not permitted to be re-operated.

Nonetheless, the implementation of those policies was then proven to be a fiasco due to its lax and premature imposition. Although the Jakarta government has confirmed that their series of civil penalties and decrees for the COVID19 pandemic (Governor Regulation (Pergub) 79/2020 concerning the Discipline and Law Enforcement of Health Protocols, Pergub80/2020, Pergub 80/2020 (the replacement of Pergub 51/2020) concerning the Implementation of Large Scale Social Restriction in Transition Period, Pergub51/2020 Implementation of Large Scale Social Restriction in Transition Period, Pergub 41/2020 concerning the Sanctions Against the Violation of the Large Scale Social Restrictions) will still and be imposed, its substantive nature were not fundamentally deterrent and its subsequent implementations were not sufficiently strict [32].

Furthermore, one of the contributing factors behind the rapid rise of confirmed COVID-19 cases in Jakarta is due to its relatively high number of COVID-19 testing and contact tracings conducted. In September, from the average daily national number of 31.000 people being tested, almost $50 \%$ of the tests were conducted in Jakarta [33]. In relation to the COVID-19 population testing standards that were provided by the World Health Organizations (WHO), the number of tests performed in Jakarta is 6.000 tests per million, which is higher than WHO standard of 1.000 tests per million [34]. This testing disparity between Jakarta and its other regional counterparts is currently one of the pandemic handling issues that is still needed to be addressed.

\section{HOW JAKARTA DEAL WITH THE ALLEGEDLY SECOND WAVE OF CORONAVIRUS}

\section{A. How Jakarta Past Events become Learning Loop that Enable Adaptive Governance}

The first difference in the response of the Jakarta Provincial Government (Pemprov Jakarta) to the handling of COVID-19 in the second half of 2020 can be seen from the adjustment of Trans Jakarta busway operational hours, 
passengers capacity, and the closure of tourism routes [35]. The same policy also applies to commuter lines within the Greater Jakarta area. In the early stage of COVID-19, between January-March, the initial response from Pemprov Jakarta to the prevention of the virus transmission was through minimizing the potential short-distance interactions between passengers by limiting operational hours and bus fleets of Trans Jakarta busway. This resulted in unmonitored and massive queues which were then regarded as counterproductive by the Ministry of Transportation, and invited criticism from all societal actors [36]. Though Pemprov Jakarta was able to respond to the crisis rather quickly, here we also find that agility does not always provide the most appropriate answer to a crisis, at least without careful preparation. The line between agility and overreaction may be thin in a crisis Janssen and Voort [30] formulating measures solely based on the virtue of reactiveness may lead to a detrimental aftermath, or in this case counterproductive [30].

The second difference is from how Pemprov Jakarta manages social assistance for the community. In the first stage of the distribution of social assistance there were several problems emerged primarily related to the inaccuracy of the aid distributions. Several news outlets reported that the aid distribution was not distributed equally. A number of lowincome households were disconnected from the program while people who are classified from the upper-class household received the support [37]. Furthermore, there was an overlap of the aid recipient, as there were separate programs of social assistance. The Minister of Social Affairs found there were residents that received aid from both the Ministry of Social Affairs and Pemprov DKI. This resulted in a chaotic operational environment. Though the government claimed that the majority of aid was on target, it still invited a fair number of criticism from both the central government and the general public [38]. However, in this case the dysfunction of social assistance programs also reflects badly on the central government on account of weak inventory data between the central and local government. Additionally, poor multilevel coordination between also institutes the miss-targeted aid distributions and overlapping activities. The problem arose due to the fact that aid distributions heavily relied on the availability of population data and thus inaccurate aggregate data due to the absence of regular updates by local municipalities resulted in defective aid distributions. Reflecting on the issue, Pemprov Jakarta together with the Ministry of Social Affairs have constructed alternative zoning mechanisms for future aid distributions [39]. This mechanism will also apply for aid distribution in the second half of 2020. As for Jakarta's data the government said that they have been working in streamlining necessary data.

In the Jakarta's case bureaucracy is one that accommodates adaptive transformation of social assistance programs, on which this can even be applied for greater extent in disaster management. While bureaucracy is often associated as antithetical to adaptability due to slow operational nature, it also plays a vital role in a crisis as it needs to be able to quickly implement new policies and measures and to ensure compliance with policies [30]. MultiLevel coordination between the Central Government and Jakarta demonstrates how bureaucracy acts as evaluator that can help to identify critical blind spot and coerce constituent bodies within its order to tweak their system accordingly.
Furthermore, multilayered institutions which are akin to bureaucracy is an important characteristic of adaptive governance in the context of natural hazards [11].

From the two cases, Jakarta demonstrates that (1) agile governance often emphasized more on reactive response which is usually followed by agile working methods; however, it does not always provide the most appropriate measures and may have yield in detrimental aftermath. (2) Bureaucracy provides reliability and proved able to facilitate adaptability. And from both cases we also found that in conflict sometimes can facilitate adaptability [30]. During the crisis Jakarta may have experienced one of the most substantial lessons in disaster management, it gave deliberative space for the system to adapt, and therefore increase its resilience to natural hazards [11].

\section{B. The Absence of Contingency Planning and Ineffective Crisis response}

As mentioned above it is necessary to have a sufficient plan both prior or after a health crisis (Efstathiou et al., [18]). A plan to lessen risk damages when it occurs notably known as contingency plans. Contingency plans are 'bundles' of policy instruments marshalled towards preparedness for crisis [40]. Contingency plans help to prepare an organization to react well to a crisis and its expected catastrophic consequences. Within the realm of disease outbreak, carefully designed advance planning can greatly reduce the impact, scale and cost of the outbreak [41]. Needless to say, the contingency plan has never been more urgent and plays no small role in combating COVID-19. Nonetheless, only a limited number of regional governments have a solid contingency plan to account for a new reality created by COVID-19.

Jakarta apart from being the administrative center in Indonesia, seems to have suffered from lack of preparedness in handling disease outbreaks. This hinders appropriate responses to be delivered by Pemprov Jakarta. Evidently two cases that previously described show a deficient response in the early phases of the pandemic. However, other factors that influence Jakarta's response should also take into account. The absence of a national predefined response plan being one of the many reasons for the lack of well-orchestrated response from the regional government. The main, and probably the only reference, for management of infectious disease is decades long regulation (Government Regulations 40/1991) and medical and health management guidelines only come into terms 3 months after the official COVID-19 announcement [42]. As for Jakarta, instruction to the head of Health Officer to be involved in the preparation of contingency plans may indicate that previously the region never had any advance planning related to outbreak handling (Jakarta Governor Instruction 16/2020) [43]. Though, how the plan will be manifested is still unknown. Errikson et al [40] enunciate weak planning or even the absence of a contingency plan, is a major causal factor in producing ineffective crisis response [40].

As Efstathiou et al [18] mentioned that it is of utmost importance in a health crisis to have an administrator that possess appropriate experiences [18]. Though, the discussion was mainly about the health crisis in an organizational context, hence the managers, the point regarding adequate ability and experience are crucial and should be considered for 
this discussion. Pemprov Jakarta, which does not have a prior health crisis contingency plan and limited experience in handling full-blown nationwide health crises such as COVID19, severely hampered the delivery of effective crisis management. It's only fair that criticism directed for Pemprov Jakarta's crisis management comes with a plausible situational explanation that affects both the area and the government. One could argue that the ineffective crisis management is the result of deficient disaster governance, but we also should not discredit previous endeavor as well as external factors that affect the governance.

\section{CONCLUSION}

Entering the second half of 2020, Jakarta Province experienced a surge in COVID-19 cases. The escalation was mainly due to the relaxation of the social restriction (PSBB) policy and the introduction of a transitional phase which took effect from June to September. The failed attempt to flatten the COVID-19 curve and the exponential increase in cases that occurred during the transition phase indicate that policy change was one of the triggers for the cases explosion in Jakarta. Although this predicament reflects the failure of Pemprov Jakarta's early crisis management, this event has also become a learning medium that enables adaptive governance. Based on an agile and adaptive governance theoretical framework, we can conclude that agile governance is generally reactive in nature and does not always provide appropriate treatment, this can be seen from the public transport restriction policies which renders an adverse effect in the end. And a crisis can facilitate the government transformation towards adaptive governance, this can be seen from an improvement in responses and mechanisms of public transport policies as well as social assistance. Lastly, although bureaucracy is often associated as an antithesis of adaptive governance in this case it facilitates the adaptability of the local government.

\section{ACKNOWLEDGMENT}

This research entitled: Analysis of COVID-19 Policy Governance at the National and Regional level was funded by BP-PTNBH Kemenristek of Indonesia / BRIN 2020 research funding awarded to Dr. Saut Sagala. The authors received assistance from Dimas Mahardika and Satrio Imam for the data collection.

\section{REFERENCES}

[1] L. Barron, "A Silent Epidemic? Experts fear the Coronavirus is spreading undetected in Southeast Asia," February 28, 2020, 2020. https://time.com/5792180/southeast-asia-undetected-coronavirus/ (accessed Sep. 21, 2020)

[2] "Jakarta COVID-19 monitoring," 2020. https://corona.jakarta.go.id/id (accessed Sep. 22, 1BC)

[3] I. Suraya, M. I. Nurmansyah, E. Rachmawati, B. Al Aufa, and I. I Koire, "The impact of large-scale social restrictions on the incidence of covid-19: A case study of four provinces in Indonesia," Natl. Public Heal. J., vol. 15, no. 2 (2020), pp. 49-53, 2020, doi 10.21109/KESMAS.V15I2.3990.

[4] Muhyiddin Muhyiddin, "COVID-19, new normal, and development planning in Indonesia (COVID-19, new normal, dan perencanaan pembangunan di Indonesia)," J. Perenc. Pembang. Indones. J. Dev. Plan., 2020, doi: 10.36574/jpp.v4i2.118.

[5] B. Sutrisno, "Transitional PSBB': A deciding chapter for Jakarta's new normal," June 9, 2020 https://www.thejakartapost.com/news/2020/06/09/transitional-psbba-deciding-chapter-for-jakartas-new-normal.html (accessed Sep. 23, 2020)
[6] L. Diana, "Jakarta COVID-19 positivity rate hit 9.2 percent this week," 18 August, 2020. https://en.tempo.co/read/1377164/jakartacovid-19-positivity-rate-hit-9-2-percent-this-week (accessed Sep. 21, 2020).

[7] Yustinus Paat, "The DKI Provincial Government reveals the causes of increased COVID-19 cases at the transitional PSBB (Pemprov DKI ungkap penyebab kasus COVID-19 meningkat di PSBB transisi)," July $18, \quad 2020 . \quad$ https://www.beritasatu.com/whisnu-bagusprasetyo/megapolitan/656655/pemprov-dki-ungkap-penyebab-kasuscovid19-meningkat-di-psbb-transisi (accessed Sep. 22, 2020).

[8] "Tests reveal increase in COVID-19 clusters in Jakarta's houses of worship," August 2, 2020. https://www.thejakartapost.com/news/2020/08/01/tests-revealincrease-in-covid-19-clusters-in-jakartas-houses-of-worship.html (accessed Sep. 23, 2020).

[9] R. Djalante et al., "Review and analysis of current responses to COVID-19 in Indonesia: Period of January to March 2020," Prog. Disaster Sci., vol. 6, no. SI: COVID-19 Special Collection, pp. 1-9, 2020, doi: 10.1016/j.pdisas.2020.100091.

[10] C. Pearson, "A blueprint for crisis management," Ivey Bus. J., vol. 66 no. 3, no. January / February 2002, pp. 69-69, 2002, [Online]. Available: https://iveybusinessjournal.com/publication/a-blueprintfor-crisis-management/.

[11] R. Djalante, C. Holley, and F. Thomalla, "Adaptive governance and managing resilience to natural hazards," Int. J. Disaster Risk Sci., vol. 2, no. 4, pp. 1-14, 2011, doi: 10.1007/s13753-011-0015-6.

[12] C. M. Giannantonio, "Book review: Krippendorff, K. (2004). content analysis: An introduction to Its methodology (2nd ed.). Thousand Oaks, CA: Sage," Organ. Res. Methods, 2010, doi: $10.1177 / 1094428108324513$

[13] M. D. White and E. E. Marsh, "Content analysis: A flexible methodology," Libr. Trends, vol. 55, no. 1, pp. 22-45, 2006, doi: 10.1353/lib.2006.0053.

[14] W. T. Coombs, "Attribution Theory as a guide for post-crisis communication research," Public Relat. Rev., vol. 33, no. 2, pp. 135139, 2007, doi: 10.1016/j.pubrev.2006.11.016.

[15] C. M. Pearson and J. A. Clair, "Reframing crisis management," Acad. Manag. Rev., 1998, doi: 10.5465/AMR.1998.192960.

[16] W. T. Coombs, "The protective powers of crisis response strategies: Managing reputational assets during a crisis," J. Promot. Manag., vol. 12, no. 3-4, pp. 241-260, 2006, doi: 10.1300/J057v12n03_13.

[17] L. Barton, Crisis in Organizations II. 2001

[18] Z. M. Panos Efstathiou, Dafni Papafragkaki, Kostas Gogosis, "Crisis Management in the Health Sector: Qualities and characteristics of health crisis managers," Int. J. Caring Sci., vol. 2, no. 3, pp. 105-107, 2009.

[19] A. Boyd, N. Chambers, S. French, D. Shaw, R. King, and A. Whitehead, "Emergency planning and management in health care: priority research topics," Heal. Syst., vol. 3, no. 2, pp. 83-92, 2014, doi: $10.1057 / \mathrm{hs} .2013 .15$

[20] Laws of the Republic Indonesia number 6 of 2018 about health quarantine (Undang-undang Republik Indonesia nomor 6 tahun 2018 tentang karantina kesehatan). The President of Republic Indonesia, 2018, p. 3.

[21] C. S. Holling, Adaptive environmental assessment and management. 1978.

[22] C. S. Holling, "Resilience and stability of ecological system," Annu. Rev. Ecol. Syst., vol. 4, pp. 1-23, 1973.

[23] R. Djalante, C. Holley, F. Thomalla, and M. Carnegie, "Pathways for adaptive and integrated disaster resilience," Natural Hazards. 2013, doi: 10.1007/s11069-013-0797-5.

[24] L. Carlsson and F. Berkes, "Co-management: Concepts and methodological implications," J. Environ. Manage., vol. 75, no. 1, pp. 65-76, 2005, doi: 10.1016/j.jenvman.2004.11.008.

[25] C. Folke, T. Hahn, P. Olsson, and J. Norberg, "Adaptive governance of social-ecological systems," Annual Review of Environment and $\begin{array}{llll}\text { Resources. } & \text { pp. 441-473, 2005, doi: }\end{array}$ 10.1146/annurev.energy.30.050504.144511.

[26] P. Olsson, C. Folke, and F. Berkes, "Adaptive comanagement for building resilience in social-ecological systems," Environ. Manage., vol. 34, no. 1, pp. 75-90, 2004, doi: 10.1007/s00267-003-0101-7. 
[27] UNISDR, Disaster risk reduction: 2007 global review. United Nations Office for Disaster Risk Reduction, 2007.

[28] E. Overby, A. Bharadwaj, and V. Sambamurthy, "Enterprise agility and the enabling role of information technology," Eur. J. Inf. Syst., vol. 15, no. 2, pp. 120-131, 2006, doi: 10.1057/palgrave.ejis.3000600.

[29] P. P. Tallon, M. Queiroz, T. Coltman, and R. Sharma, "Information technology and the search for organizational agility: A systematic review with future research possibilities," J. Strateg. Inf. Syst., vol. 28, no. 2, pp. 218-237, 2019, doi: 10.1016/j.jsis.2018.12.002

[30] M. Janssen and H. van der Voort, "Agile and adaptive governance in crisis response: Lessons from the COVID-19 pandemic," International Journal of Information Management. pp. 1-7, 2020, doi: 10.1016/j.ijinfomgt.2020.102180.

[31] M. A. Ridhoi, "Details of the fifferences in implementation of the transitional phase of the Jakarta PSBB and previously (Rincian beda pelaksanaan PSBB Jakarta fase transisi dan sebelumnya)," June 5, 2020 .

https://katadata.co.id/muhammadridhoi/berita/5ed9f19f1d2a9/rincian -beda-pelaksanaan-psbb-jakarta-fase-transisi-dan-sebelumnya (accessed Sep. 22, 1BC).

[32] A. M. Idhom, "The difference between the latest Jakarta PSBB Rules, Transitional PSBB \& PSBB Volume 1 (Beda Aturan PSBB DK Jakarta Terbaru, PSBB Transisi \& PSBB Jilid 1)," September 15, 2020. https://tirto.id/beda-aturan-psbb-dki-jakarta-terbaru-psbbtransisi-psbb-jilid-1-f4ue (accessed Sep. 21, 2020).

[33] H. Kusuma, "COVID-19 testing in Indonesia is not evenly distributed, mostly in Jakarta (Tes COVID di RI Belum Merata, Paling Banyak di Jakarta)," September 23, 2020.

[34] "DKI Deputy Governor about Corona in Jakarta high: Testing 6 times the WHO standard (Wagub DKI soal Corona di Jakarta Tinggi: Testing 6 kali lipat standar WHO)," September 23, 2020.

[35] F. Diana, "Busway schedule during PSBB tight ALa Anies (Jadwal buswaysSelama PSBB ketat ALa Anies)," September 14, 2020. https://www.cnbcindonesia.com/news/20200914124007-4186617/jadwal-busway-selama-psbb-ketat-a-la-anies (accessed Sep. $24,2020)$.
[36] P. M. S. Putra, "Ministry of Transportation asks DKI Provincial Government to evaluate Transjakarta operational limits (Kemenhub minta Pemprov DKI evaluasi pembatasan operasional Transjakarta)," March 16. https://www.liputan6.com/news/read/4203525/kemenhubminta-pemprov-dki-evaluasi-pembatasan-operasional-transjakarta (accessed Sep. 22, 2020)

[37] L. D. Wijaya, "Legislator slams Jakarta's poor data on social assistance program," April 22, 2020. https://en.tempo.co/read/1334395/legislator-slams-jakartas-poordata-on-social-assistance-program (accessed Sep. 24, 2020).

[38] "DKI social assistance overlaps, minister of social affairs criticizes Anies (Bansos DKI tumpang tindih, menteri sosial kritik Anies)," May 7, 2020. https://www.cnbcindonesia.com/news/20200507214500-4156975/bansos-dki-tumpang-tindih-menteri-sosial-kritik-anies (accessed Sep. 21, 1BC).

[39] S. Atika, "Accurate social aid data still eludes government," July 23, 2020. https://www.thejakartapost.com/news/2020/07/23/accuratesocial-aid-data-still-eludes-government.html (accessed Sep. 23, 2020).

[40] A. M. Kerstin Eriksson, "Contingency planning for crisis management: Recipe for success or political fantasy?," Policy Soc., vol. 30, no. Issue 2: Success and Failure in Crisis Management, pp. 89-99, 2011, doi: https://doi.org/10.1016/j.polsoc.2011.03.004.

[41] FOA, "Part I - Asia regional technical guidelines." http://www.fao.org/3/X8485E/x8485e05.htm\#TopOfPage (accessed Sep. 22, 2020)

42] BNPB, Guidelines for COVID-19 medical and health rapid management in Indonesia (Pedoman penanganan cepat medis dan kesehatan COVID-19 di Indonesia). Jakarta: Indonesia National Agency for Disaster Manegement, 2020.

[43] P. Jakarta, Special regional governor instructions capital city of Jakarta number 16 of 2020 about improved awareness of the risk transmission Coronavirus disease infections (COVID-19). Provincial Government of DKI Jakarta, 2020, pp. 2-4. 